\title{
Making the most of introverted leadership in a world of extroverts
}

\author{
Ekta Agarwal, MBA student \\ e.agarwal.185@westcliff.edu
}

\begin{abstract}
In this competitive world everyone strives to become a good leader. Generally, people have a notion that extroverts are better leaders than introverts (Cain, 2013). But recent results (Cain, 2013), are in contradiction with these peoples' beliefs. As we advance in our careers, individual expectations increase as we need to collaborate with others for the growth of the organization (Helgoe, 2013). Due to these expectations, extroverts have the edge when compared to introverts, and hence, this leads to the capabilities of introverts being overlooked (Eve-Cahoon, 2003). It is a general human tendency to define confidence with a person's level of loudness. As per the research by Laney (2002), loudness should not be a criterion to measure confidence. Being perplexed about our own behavior is the biggest mistake people make. Firstly, people need to understand which scale they pertain to. The research says the best way to understand this scale is by paying attention to what we do, not what we think or say (Cain, 2013). This article gives knowledge about how an introvert holds the capabilities to lead groups and inspire others. Various characteristics of introverted leadership are described with real-time examples and statistics to articulate the difference between extrovert and introvert leadership styles. The goal is not to change introverted leaders, instead it is to understand their preferences and use it as a strength (Kahnweiler, 2009).
\end{abstract}




\section{Introduction}

Traditionally, it is assumed that extroverts take up leadership roles because of their outspoken personalities and networking and public speaking skills (Helgoe, 2013). These traits are believed to be important for a leader to possess in order to drive employees. But looking back at history, many influential people with significant achievements were introverts (Kahnweiler, 2009). Introverts have excelled in many fields, such as technology, art, science, and literature. This proves that introverts also have the ability to lead organizations in an extremely extroverted culture all over the world.

Reports state that roughly $40 \%$ of executives around the world are introverts (Smith, 2013). The innate quality of these achievers is their style of working in solitude, slow yet focused and effective, with calm confidence and the biggest of all they master the art of listening (Kahnweiler, 2009). Introverts have the ability to accept mistakes, limitations, and imperfections which makes them humble (Karten, 2013). Being humble creates a way to hear others out, which leverages their listening skills. Introverts tend to take the blame and support their employees if things go wrong, and further encourage the employees to learn from their mistakes (Eve-Cahoon, 2013). Embracing solitude makes them more creative as they make space for self-learning and understanding the pros and cons of any proposition (Karten, 2013). Hence, they are often claimed as safe players and are less risk-takers. Introverts spend a lot of time in making things go smoothly and focusing on better ways to achieve goals. As Cain (2013) explains, their focus on depth helps them dig deep into problems and come up with ideas before moving on to new ones. Introvert leaders use their weaknesses to seek, understand, and play to their strengths (Smith, 2013).

Society is in need of people who can be calm, quiet, and focused. Introverts are the best gift the world can have to balance a go-go, extroverted culture (Cain, 2013).

\section{Discussion}

\section{Comparing the Traits of Introverted Leadership and Extroverted Leadership}

Understanding personality traits, strengths, and weaknesses between introverts and extroverts, givens insights about behavior (Costa \& McCrae, 1985). The biggest strength for introvert is their ability to make decisions without small talk. They have a talent to foresee the 
outcome and express it in writing (Eve-Cahoon, 2003). While, the biggest strength of an extrovert is being social and out-spoken. Table 1 illustrates some of the traits of both introverted and extroverted leaders (Kahnweiler, 2009).

Table 1

Leadership characteristics

\begin{tabular}{|l|l|}
\hline Introverted leadership characteristics & Extroverted leadership characteristics \\
\hline Depth to breadth & Breadth to depth \\
\hline Learn by listening & Learn by speaking \\
\hline Slow thinkers & Fast speakers \\
\hline Value people more than work & Value work more than the people \\
\hline Think to talk & Talk to think \\
\hline Action oriented & Voice oriented \\
\hline
\end{tabular}

Note: Traits of Introverted Leadership and Extroverted Leadership (Kahnweiler, 2009) Introverted Leadership Traits

Learn by listening. The best skill in introverted leaders is their ability to listen. This helps them make better decisions and hear every voice in the group (Cain, 2013). They pay attention to detail and learn to analyze every detail for any given problem. They exhibit their view only once they are prepared, have processed, have analyzed, and have connected with people around them (Kuofie, Stephens-Craig, \& Dool, 2015). For example, according to the research from Wharton professor Adam Grant (2009), in a classroom discussion, an introverted student does not participate until he/she learns the mechanics of the discussion. They speak to add valuable comments only when they are able to articulate the importance of it.

Think first talk later. The biggest difference between introverted leaders and extroverted leaders is, introvert leaders think first and talk later (Cain, 2013). Mark Zuckerberg, CEO of Facebook, built one of the most successful technological companies in the world. No one must have ever heard about what was going with the idea of Facebook until it was launched. He is a perfect example of a person who implements his creative idea, and then, let the world know about it (Humphrey, 2013). 
Making the most if given a chance. Introverted leaders wait for opportunities to be given to them and proves that they are valuable. In a common scenario, introverted leaders do not speak up until asked to. Once, they make an attempt, they make the most out of it. They express themselves in their unique way and make sure others hear them (Kahnweiler, 2009). The best compliment I received from my professor was even though I do not speak much in class, when I do speak, I always make the interaction meaningful.

People are more important than work. In a group of people in any organization, extroverts think about how the work can be done. They collaborate and motivate people as a group to get the work done (Eve-Cahoon, 2003). In the same situation, introverts think how individuals in the group can nurture his/her skills while contributing for the work. Introverted leaders think about every individual in the group and try to collaborate with and motivate them one-on-one for their personal growth (Laney, 2002).

Valuable assets for extroverted leaders. In a group, if there are only extroverts, there will be several conflicts due to their outspoken nature. For a team, it is essential to have a few introverts around to value everyone's perspectives (Berkowitz, 1953). For example, a worldfamous cricketer, Sachin Tendulkar, was made captain of his team. Under his captaincy, India won $16 \%$ of the time (Purandare \& Guha, 2012). He was an extreme introvert and the whole team was very happy because their voices were heard. Though there were lot of oppositions (extroverts), he was an asset to the team as his skills made the team believe in him.

People portrayed as extroverts though they are introverts. Voice should not be the only criteria that defines a person as an introvert; their actions also need to be considered. As we have seen in history, Barack Obama, though an introvert, always proved himself through his actions and left an impact on society. His work made people think about his traits and the whole world recognized him as a perfect leader (Greenstein, 2012).

Confident but not over confident. People have the notion that introverts lack confidence because of their shyness. But as seen in the research of Cain (2013), introverts do not enjoy social interactions because that is their preference and not an aversion. From the time of childhood, we do not know what we are passionate about. Once we know about our passion, we should also understand that we can always not be successful in the first attempt go. As 
George (2004) has stated, self-confidence is the primary requirement, and then, the day one starts receiving appreciation, confidence is increased. Introverts engage much less in social interactions, but due to the time they buy-in, they think through and understand interesting insights of a scenario which makes them confident but not overly confident (George, 2004). For example, one of the most successful businessmen Elon Musk, CEO of Tesla Motors and cofounder of PayPal, definitely does not lack confidence even though he is an introvert (Vance, 2015). Elon Musk (2016) said, "If something's more important enough, you should try. Even if you - the probable outcome is failure."

\section{Recommendations}

The key idea is to believe in ourselves, build confidence, and utilize the skills we have to be able to lead. To be successful, one needs to have, the power to learn, motivate, and be equally competitive in a group (Kuofie, Stephens-Craig, \& Dool, 2015). The ability to enhance the skills you cherish the most in yourself and to make others enhance theirs in a way where they can handle challenging situations is a goal of leadership.

\section{Conclusion}

The world looks for people who are capable of taking over challenges and proving their actions. There is no answer to the question, who are the better leaders? In fact, time has proven that both can play an important role in leadership positions. Making the most of what we have is the best way to perceive leadership (Greenstein, 2012). Introverts do not seize power, instead they lead by mentorship, listen to other's perspectives, think through every pro and con of a situation, inspire, encourage, and bring out the best in others. Introverts generally leave their egos aside and take risks only after thorough analysis (Helgoe, 2013). 


\section{REFERENCES}

Berkowitz, L. (1953). Sharing leadership in small, decision-making groups. The Journal of Abnormal and Social Psychology, 48(2), 231.

Eve-Cahoon, H. (2003). Understanding the introvert preference. Journal of Nursing Education, 42(5), 191-193.

Cain, S. (2013). Quiet: The power of introverts in a world that can't stop talking. Broadway Books.

Costa, P. T., \& McCrae, R. R. (1985). The NEO personality inventory manual. Psychological Assessment Resources, 4, 31-54.

Collins, J. (2006). Level 5 leadership: The triumph of humility and fierce resolve. Managing Innovation and Change, 234.

George, B. (2004). The journey to authenticity. Leader to Leader, 31, 29-35.

Greenstein, F. I. (2012). The presidential difference: Leadership style from FDR to Barack Obama. Princeton University Press.

Helgoe, L. A. (2013). Introvert power: Why your inner life is your hidden strength. Sourcebooks, Inc.

Humphrey, R. H. (2013). Effective leadership: Theory, cases, and applications. SAGE Publications.

Karten, N. (2013). Leading as an introvert. CIO, 73.

Kahnweiler, J. B. (2009). The introverted leader: Building on your quiet strength. Berrett-Koehler Publishers.

Kuofie, M., Stephens-Craig, D., \& Dool, R. (2015). An overview perception of introverted leaders. International Journal of Global Business, 8(1), 93.

Laney, M.O. (2002). The introvert advantage: How to thrive in an * extrovert world. New York: Workman.

Purandare, V., \& Guha, R. (2012). Sachin Tendulkar: A definitive biography. Roli Books Private Limited.

Smith, J. E. (2013). The power of introverts in a world that can't stop talking.

Vance, A. (2015). Elon Musk: How the billionaire CEO of SpaceX and Tesla is shaping our future. Random House. 